\title{
Research on the Cultivation of Innovative and Entrepreneurial Talents in Application-oriented Colleges under the Background of "Supply-side" Reform: A Case Study of Wuhan Business University
}

\author{
Zhang Yong \\ Wuhan Business University, Wuhan, 430056, China \\ E-mail: 5880161@qq.com
}

Keywords: "Supply-side” reform; Application-oriented colleges and universities; Innovation and entrepreneurship; Talents cultivation

\begin{abstract}
In the era of "innovation and entrepreneurship", studies on its development have been increasing under the background of supply-side reform. Therefore, the paper takes the research on innovation and entrepreneurship development in Wuhan Business University as a breakthrough point, summarizing problems of the talents cultivation in application-oriented colleges and universities through a questionnaire. Furthermore, under the background of supply-side reform, it can effectively contribute to the supply of talents to meet social needs by revising the cultivation mode of innovative and entrepreneurial talents, optimizing the educational teaching system, and improving the quality of talents.
\end{abstract}

\section{Introduction}

With the development of the times and the transformation of educational ideas, innovative and entrepreneurial talents have been the main targets during the process of talents cultivation in application-oriented colleges and universities. [1] In talents cultivation, it is necessary to constantly use science and technology to make the continuous improvement of the cultivation system in application-oriented colleges and universities, which is more in line with the supply-side reform. The purpose of China's implementation of supply-side reform is to maximize the diversity of talents cultivation. [2] From the perspective of national long-term development, China urgently needs innovative and entrepreneurial talents whom application-oriented colleges and universities have certain advantages in cultivating. [3] Therefore, it is necessary to set certain tasks for local application-oriented colleges and universities and make them contribute more to the development of the country.

2. Current Situation of the Cultivation of Innovative and Entrepreneurial Talents in Application-oriented Colleges and Universities under the Background of Supply-side Reform

\subsection{Scattered Supply and Insufficient Integration}

At present, although application-oriented colleges and universities seem to implement the policy of cultivating innovative and entrepreneurial talents actively, there are many problems in themselves. [4] First, the supply system is not ideal. In the process of talents cultivation, local application-oriented colleges and universities used to adopt the traditional pattern, so it is difficult to complete the transition quickly in a very short time. As a result, the fact that the overall layout of the supply appears to be scattered leads to their failure to find the key point and the secondary one, which finally makes them produce no desirable results in the talents cultivation. Second, integration is not enough. Without a rational plan, the integration of supply-side reform, the demand for innovative and entrepreneurial talents and the transition of application-oriented colleges and universities, if still made according to the empirical mode, will definitely fail to attain desirable results. 


\subsection{Single Supply Mode and Lack of Features}

For current education work, the supply-side reform has pointed out the direction of innovative and entrepreneurial talents cultivation for local application-oriented colleges and universities. [5] However, not all of them can quickly complete their own optimization and innovation. During the process of talents cultivation, local application-oriented colleges and universities which excessively rely on cooperation with enterprises may easily walk into a single road, which probably ignores some special talents and does harm to the long-term education progress. In the situation of single supply mode, these colleges and universities begin to lose their features in the cultivation of innovative and entrepreneurial talents. Many leaders and managers in these colleges and universities have no correct knowledge about this situation, which results in the growth of education concerns and puts certain pressure on some relative industries in China.

\subsection{Decentralized Resources Supply and Insufficient Sharing}

From the perspective of the supply side, the sharing work by application-oriented colleges and universities has not been completed as expected for their resources supply are decentralized severely. Firstly, some newly-growing application-oriented colleges which are not positively recognized in the education industry and have no enough resources, though advanced in educational ideas, still cannot compete with traditional counterparts. Meanwhile, they are probably eliminated in the big wave of competition, which exerts more negative influence on the cultivation of innovative and entrepreneurial talents in application-oriented colleges and universities and comprehensive cultivation of talents. Second, insufficient sharing is not caused in a short time, but it is an inevitable product of long-term fierce competition in the education sector. A good correction of this phenomenon requires gradual work instead of tough measures that cannot produce favorable results.

\section{Research on the Cultivation of Innovative and Entrepreneurial Talents in Wuhan Business University}

The present paper adopted the questionnaire and interviews to investigate 30 teachers and 200 students in Wuhan Business University. It distributed 200 questionnaires, among which 164 were collected, with a collecting rate of $82 \%$. After unqualified questionnaires were excluded, the remaining 145 were valid questionnaires. It aims to gain the current situation of the innovation and entrepreneurship education in Wuhan Business University through this investigation, reflect on its shortcomings and propose improvement measures correspondingly.

\subsection{The Effectiveness of the Innovative and Entrepreneurial Talents Cultivation Pattern}

In the question of "How effective do you think the innovative and entrepreneurial talents cultivation pattern in Wuhan Business University is?”, five choices are given, including "very effective, relatively effective, averagely effective, not very effective, and ineffective”. According to the responses, $21.4 \%$ of respondents think it is relatively effective, $42.8 \%$ averagely effective and $33.1 \%$ not very effective. It shows that most of the respondents believe the existing innovative and entrepreneurial talents cultivation pattern is averagely effective or not very effective, which indicates that there are certain problems in this pattern.

\subsection{Problems in the Construction of Teaching Staff for Innovative and Entrepreneurial Talents Cultivation}

In the multiple-choice question of "What do you think are the problems in the construction of teaching staff for innovative and entrepreneurial talents cultivation?” its choices made by respondents are analyzed. Of the responses, 57.2\% believe the main problem is lack of teachers, 48.1\% the shortage of personalized guidance and innovation, $38.3 \%$ entrepreneurial experience, and $32.6 \%$ single teaching method. Furthermore, it is found that at present most teachers responsible for innovative and entrepreneurial talents cultivation are school administrators or teachers in charge of the recruitment and employment of students. From interviews, it is known that these teachers 
suggest the relatively high difficulty and pressure for them to cultivate innovative and entrepreneurial talents, since most of them lack the experience of working in the company, let alone entrepreneurial experience. In addition, most teachers in charge of administrative affairs are busy with daily work, and they have to learn about the theory and content while conducting classroom teaching, which thus makes the cultivation effects and quality greatly reduced.

\subsection{Problems in the Cultivation of Innovative and Entrepreneurial Talents}

What problems do you think Wuhan Business University still faces in the cultivation of innovative and entrepreneurial talents? $68.5 \%$ people thinks the incomplete hardware facilities; $55.8 \%$ choose the inadequate development space for students; $45.6 \%$ think the single way to stimulate students; $34.4 \%$ hold that the help from government is not enough and the management approach is too mechanical and $21.8 \%$ maintain that the teaching model is not suitable for students' development and the theory teaching outweighs the practice.

\subsection{Main Reasons for Problems in the Cultivation of Innovative and Entrepreneurial Talents}

72.8\% respondents choose the insufficient policy advocacy; 68.5\% hold that activities are not attractive enough; $54.8 \%$ think that they ignore the cultivation of innovative abilities; $51.3 \%$ think that it is not valued by schools; $44.8 \%$ think that the class setting is excluded from the actual selection of students and $32.9 \%$ think that courses and entrepreneurial practice arrangements are unreasonable.

Through the above research and analysis, it is found that the main problems in the cultivation of innovative and entrepreneurial talents in Wuhan Business University are the imperfect curriculum system for innovation and entrepreneurship education, the lack of faculty and educational practice platforms. The specific performance is as follows: currently Wuhan Business University's cultural; employment counseling, professional courses and after-school practical activities designed for innovation and entrepreneurship education are relatively fragmented, failing to constitute a system, so it is difficult to meet the needs of systematic education for innovative and entrepreneurial talents. There are many problems in the teachers of the innovation and entrepreneurship classes in Wuhan Business University, such as the shortage of professionals, single institutions, simple professional concepts, and lack of entrepreneurial experience. Moreover, training centers, laboratories and technology centers are the main venues for daily teaching, but the openness of these venues is still limited.

\section{Referential Significance of Supply-side Reform to the Cultivation of Innovation and Entrepreneurial Talents in Wuhan Business University}

Innovation and entrepreneurship education will be the trend of higher education reform in the 21st century and the essence of innovation and entrepreneurship education is to cultivate students' innovative spirit and entrepreneurial ability. Adjustment of the industrial structure determines the adjustment of the talent demand structure and sound development of enrollment and employment can be achieved only if the disciplines of the Wuhan Business University are set properly. The supply-side structural reform requires colleges and universities to develop students from the perspective of long-term development and they should start from what kind of students should be cultivated in colleges and universities and how to train students, adjust professional settings and curriculum settings, and change school systems in an effort to improve the quality, efficiency and innovation of personnel.

\subsection{Making Use of Big Data to Achieve the Balance between Talent Supply and Demand}

Under the supply-side reform of the talents cultivation model, Wuhan Business University should take full advantage of the big data platform. It should be stimulated by the demand side and promoted by the supply side, changing the thinking mode of "taking it for granted" and "closed doors". Wuhan Business School should timely adjust personnel training structure, create new specialties, delete certain over-supply professional talents under economic restructuring by grasping 
the new demand and changes of local economic development in Hubei Province in order to achieve the balance of talent supply and demand, and provide talents meeting the needs of enterprises.

\subsection{Focusing on the Economic Development of Hubei Province and Setting up Majors in Harmony with the Demand Structure of Local Industries}

Colleges and universities should fundamentally change the way of setting up majors for the purpose of enrollment and they should set up majors suitable for local economic development, and cultivate talents that meet the needs of local economic development. They should coordinate major setup with the industrial structure, focusing on Hubei Province's "Thirteenth Five-Year Plan" development and key projects on current stage and cultivating professional and innovative talents in infrastructure, industrial innovation and upgrading, ecological environment and environmental protection projects. The opening of new majors in colleges and universities should be based on the actual situation of schools and social development needs, focus on teaching resources, grasp the new trends in industrial development, and give priority to the establishment of energy-saving environmental protection, green economy and other related industries.

\subsection{Reducing Repetition of the Same Content}

In teaching, there are often problems with the repetition of curriculum content, such as the establishment of a "Business Negotiation" course for international trade and the opening of "Business Communication" course at the same time. The course itself and its content is repetitive, such as the repetition of ceremonial content in the contents of "Business Communication" and "Business Etiquette", affecting the enthusiasm of students' learning and reducing the efficiency of student learning.

\subsection{Deepening School-enterprise Cooperation}

We should increase the number of corporate teachers for teaching. In the cultivation of innovative and entrepreneurial talents, corporate teachers may be increased to teach in actual combat by hiring staff that have practical experience in the enterprise to serve as practical teaching work, providing practical skills for the cultivation of talents in colleges and universities, or job training in corresponding positions. Take the training of practical skills of marketing students as an example. In the teaching process, professional teachers can collaborate with corporate trainers to teach professional courses such as market research and customer relationship management. Professional teachers can complete professional knowledge in classroom teaching, and for practical skills, corporate trainers can be invited to give lectures in classroom. In order to reduce the impact on the company's daily work, students can also be transferred into the company where corporate trainers will give training guidance to them.

The university should set up the corporate training center which is an on-campus place for students' practical teaching. The establishment of corporate training centers is in line with the demand for personnel training under the reform of the supply side. It can not only apply the knowledge learned in professional classes to social practice, but also greatly improve students' professional and technical capabilities and social adaptability, providing high-quality talents for enterprises. We can no longer produce talents that meet the needs of modern enterprises by simply relying on the school's own strength and adopting traditional education modes and teaching methods. Universities and colleges should carry out in-depth cooperation between schools and enterprises to achieve the docking of schools and businesses. Talents needed by companies can be "order-style" trained and they will be trained and observed in the established school training center. JD Training Center helps students solve employment problems through professional grade certification, project manager's reserve, and future star recruitment to pave the way for students' employment.

\section{Conclusions}

This paper discusses the practice of innovation and entrepreneurship cultivation in the Wuhan 
Business University in the context of supply-side reform. The education work in the current stage has made great progress compared with that in the past. The overall education work tends to be sound. In the future, we should continue to take active measures in talents cultivation, consolidate the stability of the talents cultivation system and make greater contributions to national development and progress. Wuhan Business University should fully recognize the significance of the supply-side structural reform on talents cultivation and pay full attention to the training of application-oriented and innovative talents in colleges and universities. The cultivation of students' innovation and entrepreneurship should be strengthened in order to improve the quality, efficiency and innovation of talents in universities, providing high-quality human resources to achieve the goal of “Made in China 2025” in our country.

\section{Acknowledgements}

In this paper, the research was sponsored by Wuhan Business University, and the Project Name is Research on the Cultivation of Innovative and Entrepreneurial Talents in Application-oriented Colleges under the Background of "Supply-side" Reform: A Case Study of Wuhan Business University (Project No.2017025).

\section{References}

[1] A Study of Coupling Relationship between Financial Supervision and Innovation: Based on the Data of China's Commercial Bank Listed in the Form of a Shares[J]. Wei Song, Chao Yan, Xiaobao Peng, Shanshan Zheng. Journal of Financial Risk Management. 2015 (01)

[2] The End of China'’s Demographic Dividend: The Perspective of Potential GDP Growth. Cai, F, Y Lu. China: A New Model for Growth and Development. 2013

[3] Evidence on the Role of Public Policy. Research Policy. 2005

[4] Review of The Truth About Supply-Side Economics. Roberts, Paul Craig. Political Science. 1984

[5] Review of A Guide to Supply-Side Economics. Anderson, Barry L. The Accounting Historians Journal. 1982 